\title{
Migrants' Remittances in Romania and Balkan Countries:A Macro-Economic Perspective
}

\author{
Zizi Goschin, Bucharest Academy of Economic Studies \\ Aura Popa, Bucharest Academy of Economic Studies \\ Mihai Roman, Bucharest Academy of Economic Studies
}

\begin{abstract}
The remittances of international migrants contribute to the well-being of their households of origin and also have an impact at macro-economic level. Out-migration is an effective means for low-income households to quickly overcome shortages of income. The sustenance of poor households might have been more difficult without such remittances. From a macroperspective, remittances contribute to the equalization of the income distribution among households having out-migrants. This study examines the significance of selected macroeconomic and demographic factors associated with remittance behaviour in Romania and several Balkan countries (Bulgaria, Turkey and Albania) as characterized by the propensity to remit and the amount remitted. The extent to which remittances affect the living standard of house-holds left behind is also appraised.

In this respect we used macroeconomic datasets provided by World Bank and national statistical institutes. We develop a model to study the effects of migration and remittances on inequality in the origin communities, by employing regression analysis. Among the main findings is that the evolution of the regional Gross Domestic Product is positively related to the growth of the amount of remittances conveyed through the official network as part of the total amount of remittances.
\end{abstract}

JEL codes: C70, F22, F24

\section{Introduction}

In previous years, benefits from economic globalization have bypassed most developing countries, and as a result international labour migration has taken on a new and special importance. However, the impact of remittances on migrant origins is still a subject that was considerably debated through this period of time. Research all over the world tried to analyse this matter, some of them found that remittances tend to increase income inequailties, whereas others find just the opposite.

In the past few years, there has been a remarkable renaissance in the interest in remittances. This interest has undoubtedly been triggered by a striking increase in remittance flows: after years of relative neglect, they have been rediscovered as a potential source of development finance.

However, the current debate on migration, remittances and development suffers from a number of shortcomings. Also, the current "remittance euphoria" often coincides with a certain perception that it concerns a "new" issue.

\section{A Conceptual Review of the Literature}

In the current world economy, remittances from international labour migration are mostly viewed as a popular response by the Third World failure of both formal and spontaneous means to equalize the income between all the countries. In 1978, Frank and later within one year, Wallerstein considered international migrants just as another example from several flows of the market (commodities, capital, entrepreneurship, inventions, labour) manipulated by international capital in achivieng its goal of controlling the world economy, structuralist seeing migrants just as some „unwiling pawns dependent on forces outside their control that disrupt 
their lives, destroy their livelihoods, and create new cleavages in local economies and societies".

Later, in the 1980s, in the international migration literature, „market triumphalists” such as Peet and Watts (1993) showed that a migrants decision to leave their country is based more on individual families rsponding to primary human needs rathen than being some marionettes of the invisible hand that controls the entire market.

Labour migration represents the temporary or permanent movement of persons from one country to another in the pursuit of employment or education, or to escape an adverse political climate (Goldin and Reinert, 2006).

The growing volume of emigration has called for increased attention both from academics and practitioners. The existing literature dealing with migration issues usually adopts either the perspective of receiving countries (Sassen, 1988), or the causality and impact for migrantsending countries, with remittances playing a major role in this context. Migration and remittances do undoubtedly relieve pressure on the sending countries, compensating for underemployment and generating new opportunities to capture resources through remittances (Gammage, 2006), help alleviate poverty and improve quality of life in poor countries (Ratha, 2004; Skeldon, 2007). On the other hand remittances stimulate imported goods consumption, favour price increases (especially real estate) and land speculation, finally increasing inequality (Aizenman, 2006).

One major direction of investigation in the existing literature on migration and remittances is oriented around poverty as the main explanatory factor of migration. Skeldon (2005) demonstrates that poverty may be considered a root cause of migration. Some scholars argue that migration providing a way out of poverty is likely to be "primarily intra-country", since the poorest cannot afford "the cost and risk" of migration abroad (Skeldon, 2005: 255). Internal migration has received less attention in the literature of migration and development, although in many countries it has played a more significant role than the international migration (DeWind and Haldway, 2005).

Another issue of interest in the debate on migration and remittances concerns the education level of the migrants. Since the brain-drain impairs the quality of labour force and consequently the prospects for development in sending countries, it tends to be the focus of attention both in public debates and in statistics, while unskilled migration is less visible in statistics (Sabogal and Nuñez, 2010). Skilled migration may also bring about benefits through remittances, investments, or transfer of skill and technology across borders (Kageyama, 2008).

While statistical data documents a constant increase in the global volume of migrant remittances, a matter of interest are the unrecorded remittances such as hand-carries by friends and family members, in-kind remittances, consumer goods etc. These informal remittances may reach a high share, up to $50 \%$ of total, in some countries (Puri and Ritzema, 1999). Some studies suggest that unrecorded remittances are going down (Ratha, 2005) owing to better technology and efforts to reduce money laundering.

The increase of total remittances from labour migration in the world triggered the debates on their broader economic impacts on the remittance-receiving countries. One common measure employed in empirical work attempting to capture the income distribution effects of remittances is the Gini inequality index (Stark et al., 1988), but the results of such empirical analysis are contradictory. Ahlburg (1996) and Taylor (1999) reported that remittances had an equalizing effect on income distribution in Tonga and Mexico. On the contrary, Adams (1991), using the same Gini index formula, discovered that remittances contribute to the increase in inequality, mainly because better-off families are more able to pay for the costs of migration (Straubhaar and Vadean, 2006). Similar results were reported, in the Philippines, where as much as $7.5 \%$ rise in rural income inequality in the 1980s was produced by remittances, although their share in the households' income was rather low (Rodriguez, 1998), as well as in Peru (Takenaka and Pren, 2010) and in Yugoslavia, where the remittances generally fueled 
income divergence, the effects varying according to the periods and social categories (Milanovic, 1987).

Straubhaar and Vadean (2006) found two potential explanations for this lack of conclusive evidence on the remittances impact on income inequality in home countries: the diversity in the environments researched in terms of initial inequality and the differences in the methodology as well. The impact of remittances, finally depends on the nature of emigration, as well as on the socioeconomic structure, of the home country (World Bank, 2006, 2008; Beine, Docquier, and Rapoport, 2002).

A more sophisticated approach based on a dynamic model of migration and income distribution (Stark et al., 1986, 1988) revealed that the income distribution effect of remittances depends critically on the migration history and on the distribution of migration opportunities across households. They found an inverse U-shape relationship between migration and income distribution: in the first stage wealthy families benefit from the migration, therefore income inequality upsurges, while in the second stage poor families also acquire information, start migrating and take advantage from remittances, inducing a decrease in inequality.

The extent of the migrant remittances' influence in the home countries is expressed through their multiplier effects. For instance the multiplier effect from the expenditure on remittances in Mexico was 3.25 in 1988 (Durand et al, 1996), but seem to have had very limited impact on productive activities in El Salvador (Gammage, 2006), where remittances have increased the trade deficit, determining higher dependency on imports.

\section{Econometric model}

Following increasing interest and significant public debate on this topic in recent years, our paper addresses two critical research questions: how significant are remittances as a factor of poverty and inequality lowering and what factors influence the volume of remmitance flows.

We address these questions by means of an econometric model using datasets provided by World Bank and national statistical institutes with remittance behaviour in Romania and several Balkan countries, such as Bulgaria, Turkey or Albania, as characterized by the propensity to remit and amount remitted. We develop a model to study the effects of migration and remittances on inequality in the origin communities, by employing regression analysis. Among the main findings is that the evolution of the regional Gross Domestic Product is positively related to the growth of the amount of remittances conveyed through the official network as part of the total amount of remittances. The extent to which remittances affect the living standard of house-holds left behind is also appraised.

First, we have found little data concerning Albania, and only yearly sets. Also another major inconvenience was the period of time that we had to limit our analysis to: from 1994 to 2008 , in order to provide a normal comparability between these four countries. Starting our model from a simple regression, in which the dependent variable is household final consumption on expediture per capita (HFC) (constant 2000 US\$) and the independent ones are remittances (REM), in US\$ milions, the GDP per capita, in constant 2000 US\$, we try to compose a more complex equation, introducing one by one other variables, macro-economic indicators such as: deposit interest rate (DEP) (\%), total unemployment (UNM) (percentage of total labour force), inflation (INF) (at consumer prices, annual \%), patent applications by residents (PAT), consumer price index (CPI) (considered in 2005 equal to 100), and imports (IMP) and exports (EXP) of goods and services (\% of GDP).

Because of too little space for describing each result from all these calculi, we will present and focalize only on those models that were validated from the statistical point of view and that are representative for each country in particular. Therefore, we will summarize the Pearson correlation among variables found for each country in table 2 as follows: 


\begin{tabular}{|l|crrr|}
\hline & Albania & \multicolumn{1}{c}{ Bulgaria } & Romania & Turkey \\
\hline REM & 1,000 & 1,000 & 1,000 & 1,000 \\
GDP & 0,971 & 0,942 & 0,932 & $-0,640$ \\
UNM & NA & $-0,642$ & $-0,399$ & $-0,928$ \\
HFC & 0,870 & 0,947 & 0,883 & $-0,625$ \\
\hline
\end{tabular}

Table 2. Pearson correlation between remittances and the rest of the variables.

Note: In Albania's unemployment case, we didn't have enough data for the entire period, so we decided to omit this variable.

Even though we expected from our literature review, that remittances over import, export and deposit interest rate, more the first one among the two, to have a big influence, from our calculus results there is a very weak correlation and therefore we decided to not take these variables into further consideration, given the following general model in equation (1):

$$
\text { HFCit }=\beta 1 * \text { GDPit }+\beta 2 * \text { IMPit }+\beta 3 * \text { REMit }+\beta 4 * \text { UNMit }+\alpha+\varepsilon i t \text { (1) }
$$

where $t=1994,2008$ and $i=A, B, R, T$ (abbreviated as Albania-A, Bulgaria-B, Romania-R and Turkey-T).

\begin{tabular}{|l|c|c|c|}
\hline & $\begin{array}{c}\text { Coefficients } \\
\text { (T-Statistic) }\end{array}$ & \multicolumn{2}{|c}{} \\
\hline Variable & Albania & Bulgaria & Romania \\
\hline GDP & $0,456^{* *}$ & $0,905^{* * *}$ & $0,701^{* *}$ \\
& $(0,036)$ & $(0,001)$ & $(0,003)$ \\
\hline IMP & $16,245^{* *}$ & $-2,194$ & $16,834^{* * *}$ \\
& $(0,003)$ & $(0,462)$ & $(0,011)$ \\
\hline REM & $-0,219^{*}$ & $-0,018$ & 0,012 \\
& $(0,165)$ & $(0,618)$ & $(0,521)$ \\
\hline UNM & NA & 3,558 & $-17,358$ \\
& & $(0,389)$ & $(0,487)$ \\
\hline Constant & $-180,608$ & $-264,852^{*}$ & $-339,968^{*}$ \\
& $(0,314)$ & $(0,164)$ & $(0,174)$ \\
\hline R-square & 0,960 & 0,997 & 0,990 \\
\hline F-statistic and & $42,829^{* * *}$ & $325,500^{* * *}$ & $125,904^{* * *}$ \\
Prob (F) & $(0,000)$ & $(0,000)$ & $(0,000)$ \\
\hline
\end{tabular}

Table 3. Regression result.

Source: authors' processing based on data issued by the World Bank

*significant at $10 \%, * *$ significant at $5 \%, * * *$ significant at $1 \%$

The results from running the regressions specified in the equation (1) using the data for 1994-2008 period are reported in Table 3. The main result of the empirical estimation of the model is that GDP and imports do exert a strong influence on the household final consumption expenditure per capita in Romania. An increase in the Romanian migrants' remittances also seems to have a positive effect on the household consumption, although the coefficient is not highly significant. The level of unemployment is negatively related to the household consumption, but the low significance levels do not allow for conclusive results. The effect of the imports of goods and services have a strong direct influence over the households being the same for Romania and Albania, but a weaker and negative effect for Turkey and Bulgaria. Even though the model for Albania's case does not have the unemployment variable included because of missing data, the model is nevertheless the best fitted example of the countries, as all the coeffiecients are significant at $10 \%$.

In this paper a retrospective and forward-looking insight into Balkan migrants' remittances 
has been conducted. Specifically, it has mainly been aimed at highlighting their impact on household final consumption expenditure in comparison with the four countries that we chose. We found that GDP and imports do indeed exert a strong influence on the household final consumption expenditure per capita, as well as the Balkan migrants' remittances, as was expected. Some other variables that could be found in several other models which have been the subject of literary reviews were also tested without reaching significance in the final specification of the model that was proposed in this paper. Despite the decline induced by the current economic crisis, remittances still remain high, given that many migrants, even when faced with economic difficulties continue to send money to support their families.

\section{Conclusions}

The lack of longitudinal data on migration, remittances, and economic macro-indicators has necessitated inferring inequality change from static data. In order to ameliorate this problem, we undertook follow-up research on other indicators trying to emphasis some differences and influences that remittances have.

The results are very much alike for these four countries proving that they have similarities at the macro-economic level and the remittances induces important modifications over the same variables, mostly a negative influence on inflation and unemployment, but a positive impact over Gross Domestic Product as was expected. Although the Albanian result is more likely than the Romanian result overall, it seems that Bulgaria and Turkey are not just neighbours, but share almost the same trend related to remittances.

\section{Acknowledgements}

This paper has the support of CNCSIS grant no 1829/2008: The Effects Of Labour Force Migration And Of Demographical Structural Changes On The Dynamic Of Economics, financed under the programme IDEI, PN2.

\section{References}

- Adams, R. H., (1991), „The Effects of International Remittances on Poverty, Inequality and Development in Rural Egypt”, Research Report No. 96. Washington: International Food Policy Research Institute

- Ahlburg, D. A., (1996), „Remittances and the Income Distribution in Tonga”, Population Research and Policy Review, 15(4), p. 391-400

- Aizenman, N., (2006), "Money earned in U.S. pushes up prices in El Salvador." Washington Post, May 14

- Beine, M., Docquier, F. and Rapoport, H., (2002), „Brain Drain and LDCs’ Growth: Winners and Losers", Center for Research on Economic Development and Policy Reform Working Paper 129

- DeWind, J. and Haldway, J., (2005), "Internal and international migration in economic development", Paper presented at the Fourth Coordination Meeting on International Migration, Population Division, Department of Economic and Social Affairs, United Nations

- $\quad$ Durand, J., Parrado, E. and Massey, D. S., (1996), "International migration and development in Mexican communities", Demography 33, p. 249-264

- Frank, A. G., (1978), „Dependent accumulation and underdevelopment”, London: Macmillan Press

- $\quad$ Gammage, S., (2006), "Exporting People and Recruiting Remittances : A Development Strategy for El Salvador?", Latin American Perspectives, Issue 151, Vol. 33, No. 6 
- Goldin, I. and Reinert, K., (2006), „Globalization for Development: Trade, Finance, Aid, Migration, and Poverty", Washington DC: World Bank and MacMillan, p. 14

- Kageyama, A., (2008), "Poverty Alleviation by Migrant Remittances in Sri Lanka", South Asia Research Vol. 28 (1), p.89-108

- Maimbo, S., Adams, R., Aggarwal, R. and Passas, N., (2005), „Migrant Labor Remittances in South Asia", Washington DC: World Bank

- Milanovic, B. (1987), „Remittances and Income Distribution”, Journal of Economic Studies, 14(5), p. 24-37

- $\quad$ Peet, R. and Watts, M, (1993), „Development theory and environment in an age of market triumphalism", Economic Geography, 69, p. 227-253

- Puri, S. and Ritzema, T., (1999), „Migrant Worker Remittances, Micro Finance, and the Informal Economy: Prospects and Issues", Working Paper 21, Geneva: ILO, Social Finance Unit

- Ratha, D., (2004), “Understanding the importance of remittances”, Migration Information. http://www.migrationinformation.org

- Ratha, D., (2005), 'Worker's Remittances: An Important and Stable Source of External Development Finance', in Maimbo, S. M. and Ratha, D. (eds.), Remittances: Development Impact and Future Prospects, Washington DC: The World Bank, p. 1952

- Rodriguez, E., (1998), „International Migration and Income Distribution in the Philippines", Economic Development and Cultural Change, 46(2), p. 329-350

- Sabogal, E. and Núñez, L., (2010), "Sin Papeles: Middle- and Working-Class Peruvians in Santiago and South Florida", Latin American Perspectives, September 2010, vol. 37 (5), p. 88-105

- Sassen, S., (1988), „The Mobility of Labor and Capital: A Study in International Investment and Labor Flow”, Cambridge: Cambridge University Press, p. 6

- Skeldon, R., (2005), „Migration and Poverty: Some Issues in the Context of Asia”, in World Migration 2005: The Costs and Benefits of International Migration, Geneva: International Organization for Migration, p. 253-268

- $\quad$ Stark, O., Taylor, J. E. and Yitzhaki, S., (1986), „Remittances and Inequality”, The Economic Journal, 96(383), p. 722-740

- $\quad$ Stark, O., Taylor, J. E. and Yitzhaki, S. (1988), „Migration Remittances and Inequality: A Sensitivity Analysis Using the Extended Gini Index”, Journal of Development Economics, 28(3), p. 309-322

- Straubhaar, T. and Vadean, F. P., (2006), „International Migrant Remittances and their Role in Development", International Migration Outlook, No. 18, SOPEMI. Paris: OECD

- Skeldon, R., (2007), „On Migration and the Policy Process”, Sussex Centre for Migration Research Working Paper T20

- $\quad$ Takenaka, A. and Pren, K. A., (2010), "Leaving to Get Ahead : Assessing the Relationship between Mobility and Inequality in Peruvian Migration", Latin American Perspectives, Issue 174, Vol. 37 No. 5

- Taylor, J. E., (1999), „The New Economics of Labor Migration and the Role of Remittances", International Migration, 37(1), p. 63-86

- Taylor, E. J., (2004), "Remittances, savings, and development in migrant-sending areas", in Massey, D. and Taylor, J. E. (eds.), International Migration: Prospects and Policies in a Global Market, New York: Oxford University Press, p. 157-173 
- Wallerstein, I., (1979), „The capitalism world economy”, Cambridge: Cambridge University Press

- World Bank, (2006), „The Development Impact of Workers’ Remittances in Latin America", Washington DC

- World Bank, (2008), „Migration and Remittances Factbook 2008”, The International Bank for Development and Reconstruction, TheWorld Bank, Washington DC 